\title{
IDENTIFIKASI BENDA-BENDA MEGALITIK TERPENDAM MENGGUNAKAN METODE GEOLISTRIK HAMBATAN JENIS DISITUS TADULAKO KECAMATAN LORE TENGAH KABUPATEN POSO
}

\author{
Yuyu Lamrens Lama ${ }^{1}$, Sandra $^{1)}$, Maskur $^{1)}$ \\ 1) Jurusan Fisika, Fakultas Matematika dan Ilmu Pengetahuan Alam Universitas Tadulako
}

\begin{abstract}
ABSTRAK
Telah dilakukan penelitian di Desa Doda Kecamatan Lore Tengah Kabupaten Poso, dengan judul Identifikasi Benda-Benda Megalitik Terpendam Menggunakan Metode Geolistrik Hambatan Jenis Di Situs Tadulako. Tujuan dari penelitian ini untuk melihat sebaran bendabenda megalit yang masih terpendam dibawah permukaan. Penelitian ini menggunakan metode geolistrik hambatan jenis dengan Konfigurasi Wenner. Pengambilan data dilakukan sebanyak 4 lintasan yang tersebar di daerah penelitian. Pengolahan data menggunakan perangkat lunak Res2dinv untuk memperoleh nilai hambatan jenis yang diduga sebagai megalit terpendam. Keberadaan benda megalit diduga masih terdapat dibawah permukaan dengan indikasi nilai range hambatan jenis diatas $3.000 \mathrm{ohm}$ meter. Sebaran megalit yang terpendam diduga tersebar ke arah barat lokasi penelitian pada kedalaman rata-rata $1-2 \mathrm{~m}$.
\end{abstract}

Kata Kunci : Geolistrik, Hambatan Jenis, Megalit.

\begin{abstract}
The research was conducted in Doda Village, Central Lore, Poso District, with the title Indentity buried of megalith objects using Geoelectrical method of the type at the Tadulako Site. The porpose of this research is to know the distribution of megalith objects that are still buried in subsurface. This research method using configuration of wenner the date were collected in 4 trajectories spread in the research area. The data is processed by Res2dinv software to obtain the type of obstacle value suspected as a buried megalith. The existence of megalith objects is suspected that still exist then in subsurface with an indication of the value of the type of resistance above $3000 \Omega \mathrm{m}$. The distribution of megalith that are buried suspected speread on the west in research area at the depth of $1-2$ meters.
\end{abstract}

Keywords: Geoelectrical, Resistivity, Megalit. 


\section{PENDAHULUAN}

Megalitikum berasal dari kata mega yang berarti besar dan lithos yang berarti batu. Zaman Megalitikum biasa disebut dengan zaman batu besar, karena pada zaman ini manusia sudah dapat membuat dan meningkatkan kebudayaan yang terbuat dan batu-batu besar. Kebudayaan ini berkembang dari zaman Neolitikum sampai zaman Perunggu. Pada zaman ini manusia sudah mengenal kepercayaan, walaupun kepercayaan mereka masih dalam tingkat awal, yaitu kepercayaan terhadap roh nenek moyang. Kepercayaan ini muncul karena pengetahuan manusia sudah mulai meningkat.

Peninggalan benda-benda megalitik dapat dijumpai pada beberapa tempat atau situs salah satunya di Situs Tadulako, yang berada di Desa Doda Kecamatan Lore Tengah Kabupaten Poso. Topografi di Desa Doda terdiri dari pegunungan dan lembah. Kondisi geologi di daerah penelitian berada dalam formasi Napu yang terdiri dari batu pasir, konglomerat, batulanau dengan sisipan lempung, dan gambut.Situs Tadulako mempunyai benda-benda megalitik berupa arca, menhir dan dolmen. Menurut informasi dari masyarakat sekitar bahwa di Situs Megalit Tadulako masih memiliki benda megalitik yang terpendam di bawah permukaan tanah.

Menurut informasi bahwa batuan megalit yang ada di Situs Megalit Tadulako tersusun oleh batuan granit maka perlunya dilakukan penelitian geofisika dengan menggunakan metode geolistrik untuk mendeteksi benda megalit yang masih terpendam di bawah permukaan tanah, sehingga keberadaan benda-benda megalit untuk mengungkap sejarah, kebudayaan setempat.

(Telford, 1990), Aliran arus listrik dalam batuan dan mineral dapat digolongkan menjadi 3 macam, yaitu konduksi secara elektronik, konduksi secara elektrolitik, dan konduksi secara dielektrik a. Konduksi secara elektronik Konduksi ini terjadi jika batuan atau mineral mempunyai banyak elektron bebas sehingga arus listrik dialirkan dalam batuan atau mineral oleh elektron-elektron bebas tersebut. Aliran listrik ini juga dipengaruhi oleh sifat atau karakteristik masing-masing batuan yang dilewatinya. Salah satu sifat atau karakteristik batuan tersebut adalah resistivitas (tahanan jenis) yang menunjukan kemampuan bahan tersebut untuk menghantarkan arus listrik. Semakin besar nilai resistivitas suatu bahan maka semakin sulit bahan tersebut menghantarkan arus listrik, begitu pula sebaliknya. Resistivitas memiliki pengertian yang berbeda dengan resistansi tidak hanya bergantung pada bahan tetapi juga bergantung pada faktor geometri atau bentuk bahan tersebut, sedangkan resistansi tidak bergantung pada faktor geometri.

b. Konduksi secara elektrolit Sebagian besar batuan merupakan konduktor yang buruk dan memilki resistivitas yang sangat tinggi. Namun pada kenyataannya batuan biasanya bersifat porus dan memilki poripori yang terisi oleh fluida, terutama air. Akibatnya batuan-batuan tersebut menjadi konduktor elektrolitik, dimana konduksi arus listrik dibawa oleh ion-ion elektrolitik dalam air. Konduktivitas dan resistivitas batuan porus bergantung pada volume dan susunan poriporinya. Konduktivitas akan semakin besar jika kandungan air dalam batuan besar.

c. Konduksi secara dielektrik Konduksi ini terjadi jika batuan atau mineral bersifat dielektrik terhadap aliran arus listrik, artinya batuan dan mineral tersebut mempunyai elektron bebas sedikit, bahkan tidak sama sekali. Sifat-sifat suatu formasi dapat digambarkan dengan 3 parameter dasar, seperti konduktivitas listrik, permeabilitas magnet, dan permitivitas dielektrik 
Tabel 2.1 Nilai Hambatan Jenis Beberapa Batuan (Telford, 1990)

\begin{tabular}{|l|l|}
\hline Tipe Batuan & \multicolumn{1}{|c|}{$\begin{array}{c}\text { Nilai Hambatan } \\
\text { Jenis }(\Omega \mathrm{m})\end{array}$} \\
\hline Kelompok & $1 \times 10^{3}-10^{6}$ \\
granit & $4,5 \times 10^{3}-1,3 \times 10^{6}$ \\
Granit porifitik & $4 \times 10^{3}$ \\
Feldspar & $10^{2}-10^{6}$ \\
porifitik & $1,9 \times 10^{3}-2,8 \times 10^{4}$ \\
Syenit & $2 \times 10^{4}$ \\
Diorite & $6 \times 10^{2}-4 \times 10^{7}$ \\
porfiritik & $6,8 \times 10^{4}-3 \times 10^{6}$ \\
Dasit & $10^{2}-2,5 \times 10^{8}$ \\
Slate & $2,5 \times 10^{2}-2,5 \times 10^{8}$ \\
Gneiss & $10-2 \times 10^{8}$ \\
Marble & $2 \times 10^{3}-10^{4}$ \\
Skam & \\
Kuarsit & \\
Konglomerat & \\
\hline
\end{tabular}

Metode geolistrik hambatan jenis merupakan salah satu metode geofisika yang dapat memberikan gambaran susunan litologi atau struktur bawah permukaan suatu daerah berdasarkan sifat kelistrikan batuan. Aliran arus listrik mengalir di dalam tanah melalui batuan-batuan dan sangat dipengaruhi oleh adanya air tanah dan garam yang terkandung dalam batuan serta hadirnya mineral logam maupun panas yang tinggi (Hidayat dan Sampurno, 2015 ). Prinsip dasar metode ini adalah menginjeksikan arus ke dalam tanah

melalui elektroda arus dan menggukur harga potensial yang dihasilkan melalui elektroda potensial, dapat dilihat pada Gambar 1.

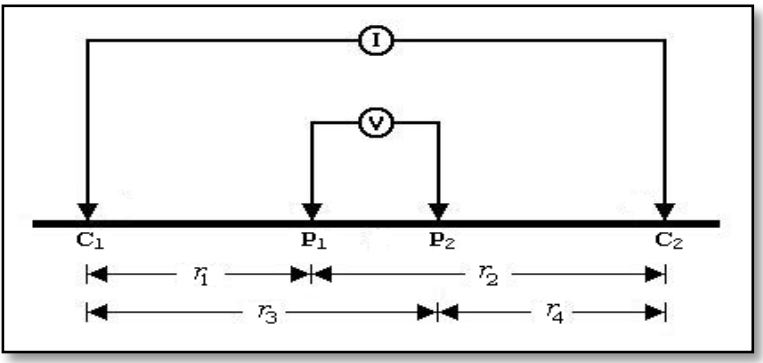

Gambar 1 Susunan Elektroda arus dan potensial pada pengukuran metode geolistrik (Santoso, 2002).

Dari besarnya arus dan beda potensial yang terukur maka nilai resistivitas dapat dihitung dengan menggunakan persamaan:

$$
\rho_{\mathrm{a}}=\mathrm{K} \frac{\Delta \mathrm{v}}{\mathrm{I}}
$$

$\mathrm{K}$ merupakan faktor geometri yang tergantung pada penempatan elektroda arus maupun elektroda potensial pada permukaan.

$$
K=\frac{2 \pi}{\left\{\left(\frac{1}{r_{1}}-\frac{1}{r_{2}}\right)-\left(\frac{1}{r_{3}}-\frac{1}{r_{4}}\right)\right\}}
$$

Metode Automatic Array Scanning (AAS) adalah metoda geolistrik hambatan jenis yang melakukan pengukuran berulang-ulang serta berurutan dengan menggunakan kedalaman penetrasi tertentu. Konfigurasi Wenner dikembangkan oleh Wenner di Amerika yang keempat buah elektrodanya terletak dalam satu garis dan simetris terhadap titik tengah. Jarak $\mathrm{P}_{1} \mathrm{P}_{2}$ pada konfigurasi Wenner selalu sepertiga (1/3) dari jarak $C_{1} C_{2}$. Bila jarak $C_{1}$ $\mathrm{C}_{2}$ diperlebar, maka jarak $\mathrm{P}_{1} \mathrm{P}_{2}$ juga harus diubah sehingga jarak $C_{1} C_{2}$ tetap (1/3) $C_{1} C_{2}$. Jarak elektroda $C_{1}$ dan $C_{2}$ dibuat 3 kali dari jarak antara 2 elektroda potensial $\left(\mathrm{P}_{1} \mathrm{P}_{2}\right)$.

Spasi antara elektroda pada konfigurasi Wenner adalah sebesar a, sehingga faktor geometrinya Persamaan 2.2 adalah:

$$
\mathrm{K}=2 \pi \mathrm{a}
$$

\section{METODE PENELITIAN}

\section{Tempat dan Waktu Penelitian}

Letak geografis lokasi penelitian yang akan di lakukan berada pada $120^{\circ} 14^{\prime} 59,19^{\prime \prime}$ BT sampai $120^{\circ} 15^{\prime} 25,62^{\prime \prime} \quad \mathrm{BT}$ dan $1^{0} 43^{\prime} 1,81^{\prime \prime}$ LS sampai $1^{0} 43^{\prime} 24,96^{\prime \prime}$ LS. Tepatnya berada di Situs Megalit Tadulako yang berada di Desa Doda Kecamatan Lore Tengah Kabupaten Poso. Jarak lokasi pengukuran dengan Desa Doda $\pm 10 \mathrm{~km}$ 
dengan waktu tempu 15 menit degan kedaraan roda empat. Lokas penelitian ini berada pada Lemba Besoa yang didominasi dengan semak belukar dan persawahan. Seperti yang terlihat pada Gambar 2

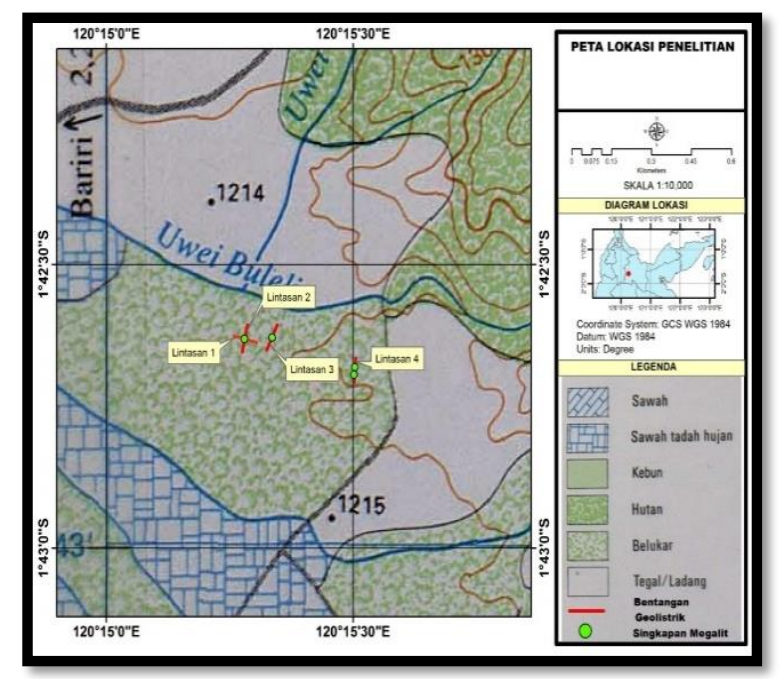

Gambar 2 Peta lokasi penelitian

\section{Alat dan Bahan Penelitian}

a. Satu set alat ukur geolistrik hambatan jenis, yaitu:

1. Alat ukur georesistivitimeter

2. Kabel 4 gulung

3. Elektroda 25 buah

4. Sumber arus listrik (accu)

5. Kabel penghubung.

a. Meteran untuk menentukan panjang spasi elektroda.

b. Global Positioning System (GPS) untuk menentukan posisi dan elevasi tiap elektroda.

c. Kompas Geologi untuk menentukan arah bentangan.

d. Peta Rupa Bumi Indonesia lembar Doda skala 1:50.000.

e. Peta Geologi Lembar Poso skala 1: 50.000

f. Palu untuk memasang elektroda. g. Alat tulis dan tabel data berfungsi untuk menginput data pengukuran.

\section{h. Software RES2DIV}

\section{Prosedur Pelaksanaan Penelitian}

\section{a. Survei Pendahuluan}

Survei pendahuluan perlu dilakukan untuk memperoleh gambaran kondisi geologi dan topografi daerah penelitian dan untuk menentukan titik-titik lokasi pengukur

Prosedur Pengambilan Data

b. Prosedur Pengambilan Data

Pengambilan data di lapangan menggunakan metode geolistrik hambatan jenis, yaitu dengan Konfigurasi Wenner. Adapun langkah-langkah yang dilakukan dalam melakukan pengukuran di lapangan adalah sebagai berikut:

1. Menentukan posisi titik pengukuran.

2. Menentukan arah bentangan dan koordinat elektroda.

3. Memasang elektroda dengan spasi 2meter tiap elektroda

4. Merangkai alat georesistiviti dan melakukan pengukuran.

5. Menginjeksikan arus ke dalam tanah melalui 2 buah elektroda arus.

6. Data yang diperoleh dari pengukuran di lapangan adalah data arus (I) dan beda potensial (V), serta jarak elektroda.

7. Untuk menghindari adanya kesalahan data, maka pada saat pengambilan data diulangi sampai 3 kali.

1) Pengolahan Data dan Interpretasi Data Pengolahan dan interpretasi data dilakukan dengan langkah-langkah sebagai berikut:

a. Menghitung faktor geometri (K) dari hasil pengukuran dengan menggunakan Persamaan (2). 
b. Menghitung nilai hambatan jenis $\rho_{\mathrm{a}}$ dari hasil pengukuran dengan menggunakan Persamaan (1).

c. Data beda potensial (V), arus (I), hambatan jenis semu $\left(\rho_{\mathrm{a}}\right)$ dan faktor geometri $(\mathrm{K})$ yang diperoleh dari hasil pengukuran kemudian diinversikan dengan program Res2dinv.

d. Hasil yang diperoleh dari program inversi berupa variasi nilai hambatan jenis, kedalaman dan ketebalan lapisan setiap bentangan yang kemudian dianalisa dan diinterpretasikan.

e. Menentukan sebaran dan kadalaman benda megalitik berdasarkan model penampang yang diperoleh dengan melihat nilai resistivitas hasil inversi.

\section{HASIL DAN PEMBAHASAN}

Secara geografis Desa Doda berada pada Lembah Besoa dengan koordinat $120^{\circ} 14^{\prime}$ 59,19"BT-120 $10^{\prime \prime} 25,62^{\prime \prime} \mathrm{BT}$ dan $1^{\circ} 43^{\prime} 1,81^{\prime \prime}$ LS- $1^{\circ} 43^{\prime} 24,96^{\prime \prime}$ LS. Sebelah selatan berbatasan dengan Pengunungan Lore Selatan, sebelah utaranya berbatasan dengan Desa Bariri. Sebelah timur berbatasan dengan Kecamatan Lore timur dan sebelah baratnya pegunungan Lore Lindu. Desa Doda berada di lembah Besoa di mana wilayah ini di kelilingi oleh pegunungan dengan kemiringan yang tidak terlalu ekstrim dengan ketinggian \pm 1250 meter di atas permukaan laut (mdpl)

Berdasarkan pengamatan kondisi geologi daerah penelitian ini tersusun atas formasi napu,. Hasil pemodelan penampang 2D yang ditampilkan dengan koreksi topografi tiap lintasan, dapat terlihat adanya batuan yang diduga sebagai megalit yang terpendam batuan ini tersusun oleh batuan granit. Dasar untuk menginterpretasi sebaran megalit yang terpendam di bawah permukaan pada daerah penelitian yaitu dengan melihat nilai hambatan jenis hasil inversi yang dipadukan dengan koreksi elevasi, kondisi geologi dan morfologi. Secara umum nilai hambatan jenis yang diperoleh pada Lintasan-1 sampai
Lintasan-4 dapat diinterpretasikan sebagai berikut:

1. Nilai hambatan jenis yang berkisar $50-$ $250 \Omega \mathrm{m}$ diduga merupakan lapisan pasir lempungan.

2. Nilai hambatan jenis yang berkisar 251 $1.150 \Omega \mathrm{m}$ diduga merupakan lapisan pasir kering.

3. Nilai hambatan jenis yang berkisar $1.151-$ $2.553 \Omega \mathrm{m}$ diduga merupakan batuan granit dimana batuan ini diduga sebagai batuan penyusun megalit.

\section{a. Lintasan-1}

Posisi pengukuran Lintasan-1 berada pada koordinat $120^{\circ} 15^{\prime} 16,8^{\prime}$ " BT dan $1^{\circ} 42^{\prime}$ ' 37,9" LS. Arah bentangan lintasan ini sebesar N $310^{\circ} \mathrm{E}$ dan berada pada ketinggian 1.231 mdpl. Pengukuran ini dilakukan di sekitar benda megalit (Patung Tadulako) yang terdapat di atas permukaan, dimana benda megalit tersebut berada pada elektroda 13 dan 14. Hasil pemodelan 2D hambatan jenis yang digabungkan dengan elevasi tiap elektroda pada Lintasan-1 diperoleh nilai hambatan jenis yang diduga sebagai megalit yaitu 1534 - $2553 \Omega$ m dengan kondisi topografi yang bervariasi (Gambar 4.5). Nilai hambatan jenis ini merupakan nilai hambatan jenis dari batuan penyusun megalit yaitu batuan granit. Batuan yang diduga sebagai megalit yang terpendam ditemukan meteran 25 di kedalaman 0 - $1 \mathrm{~m}$, dan meteran 32 pada $\mathrm{k}$ edalaman 1 - $2 \mathrm{~m}$,

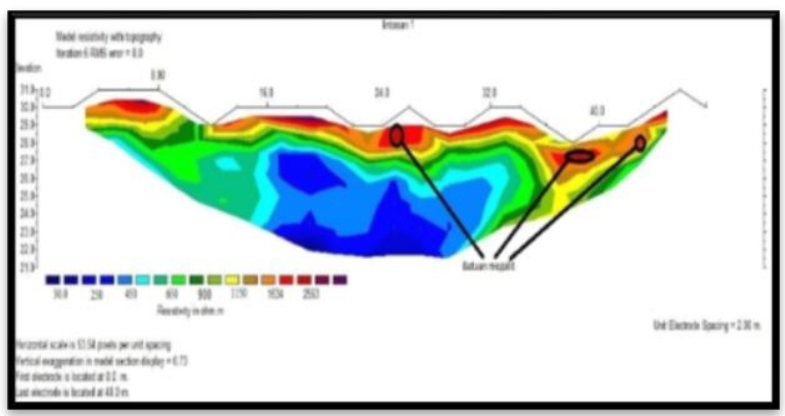

Gambar 3 Pemodelan 2D Lintasan-1 dengan koreksi topografi 


\section{b. Lintasan-2}

Pengukuran Lintasan-2 pada koordinat $120^{\circ}$ 15 ' 16,8' BT dan $1^{\circ}$ '42' 37,9' LS dengan arah bentangan $\mathrm{N} 20^{\circ}$ E. Pengukuran pada Lintasan ini dihubungkan dengan pengukuran Lintasan-1. Dimana pada lintasan ini juga terlihat adanya benda megalit yang terpendam dibawah permukaan. Pada lintasan ini kondisi topografi yang bervariasi. Pada Penampang terlihat adanya batuan diduga sebagai megalit yang terpendam dapat ditemukan pada elektroda 8, dan 17 di kedalaman $0-1 \mathrm{~m}$.

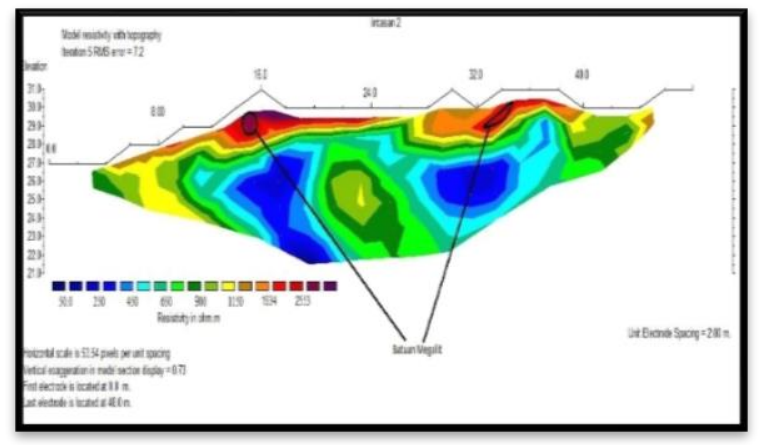

Gambar 4 Pemodelan 2D Lintasan-2 dengan koreksi topografi

\section{c. Lintasan-3}

Lokasi pengukuran lintasan 3 berada pada koordinat $120^{\circ} 15^{\prime \prime} 20.1^{\prime}$ BT dan $01^{\circ} 42^{\prime}$ " $37,9^{\prime} \mathrm{LS}$, dengan arah bentangan $\mathrm{N} 34^{\circ} \mathrm{E}$, lintasan ini berada pada ketinggian 1.238 mdpl. elevasi permukaan pada lintasan ini bervariasi dapat dilihat pada (Gambar 5). Pengukuran Lintasan-3, dilakukan dekat pada sebuah batuan mengalit yang terdapat di atas permukaan dimana batuan tersebut terdapat pada elektroda 10 dan 11. Hasil pemodelan 2D hambatan jenis menunjukan adanya batuan yang diduga sebagai megalit yang terpendam di bawah permukaan dengan nilai hambatan jenis 1534 - $2553 \Omega \mathrm{m}$. Batuan tersebut telihat pada elektroda 8 di kedalaman \pm 1 - 2 m, elektroda 10 pada kedalaman \pm 0 $1 \mathrm{~m}$, dan pada elektroda 10 di kedalaman \pm 1 -2 meter.

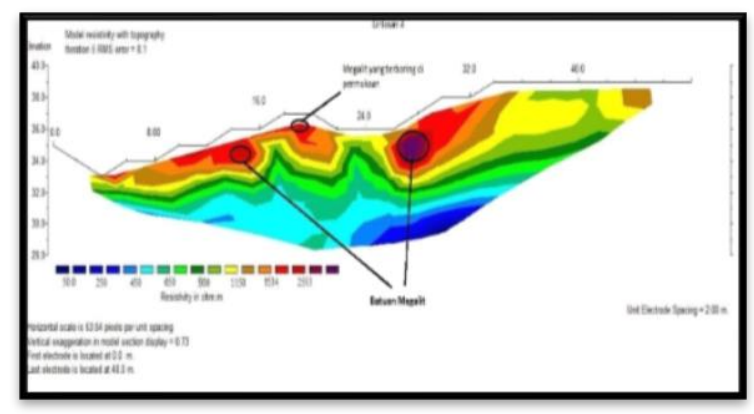

Gambar 5 Pemodelan 2D Lintasan-3 dengan koreksi topografi

\section{d. Lintasan-4}

Posisi pengukuran Lintasan-4 berada agak jauh dari lintasan sebelumnya yang berada pada ketinggian 1.283 mdpl dengan koordinat $120^{\circ} 15^{\prime} 32,2^{\prime}$ ' BT dan $1^{\circ} 42^{\prime} 41,1^{\prime \prime}$ LS dan arah bentangan $\mathrm{N} 356^{\circ}$ E. Pada Lintasan-4 terdapat 2 megalit kalamba yang berada di atas permukaan sehigga dilakukan pengukuran pada daerah ini. Pe ngukuran dilakukan dekat dengan megalit kalamba tersebut. Berdasarkan hasil pemodelan 2D dengan koreksi topografi diperoleh bahwa Lintasan-4 memiliki topografi yang bervariasi (Gambar 4.8). Hasil inversi menunjukan nilai hambatan jenis degan nilai $1.534-2553 \Omega \mathrm{m}$ yang diduga sebagai batuan granit dimana batuan ini sebgai penyusun dari batuan megalit. Batuan megalit yang terpendam pada penampang dapat dilihat pada meteran 8, meteran 14, meteran 19 pada kedalaman $0-1$ $\mathrm{m}$, dapat juga dijumpai pada meteran 28 , meteran 35 di kedalaman $\pm 1-2 \mathrm{~m}$.

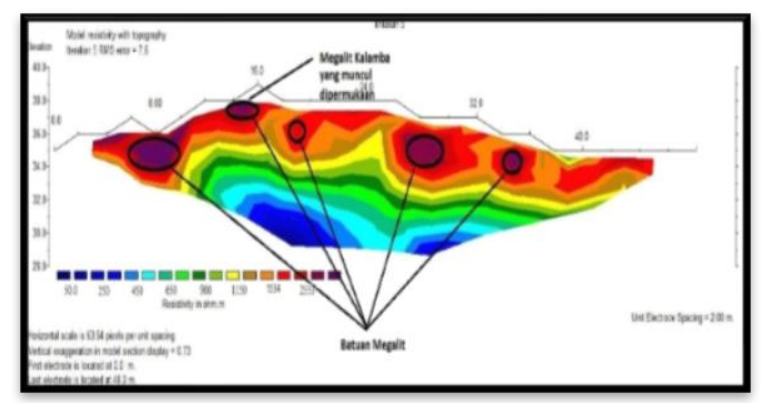

Gambar 6 Pemodelan 2D Lintasan-4 dengan koreksi topografi 


\section{KESIMPULAN DAN SARAN}

\section{Kesimpulan}

Berdasarkan hasil pengukuran geolistrik di kawasan situs Megalit Tadulako maka dapat disimpulkan bahwa, disitus megalit Tadulako diduga masih terdapat batuan megalit yang terpendam di bawah permukan. Dari hasil pemodelan 2D untuk setiap lintasan dapat meperlihatkan batuan megalit yang masih terpendam di bawah permukaan. Dengan nilai resitivitas yang diduga sebagai batuan megalit berkisar $1.151-2.553 \Omega \mathrm{m}$. Batuan megalit tersebar ke arah barat lokasi penelitian dengan rata-rata kedalaman 1 - $2 \mathrm{~m}$.

\section{Saran}

Untuk kelanjutan penelitian yang lebih baik maka perlu saran sebagai berikut

1. Adanya perhatian dari pemerintah untuk memfasilitasi penelitian lanjutan untuk mengidentifikasi di situs megalit yang lain.

2. Perlu dilakukan penelitian dengan menggunakan metode geofisika yang lain sebagai pembanding untuk mendapatkan hasil yang lebih akurat'

\section{UCAPAN TRIMAKASIH}

Trimakasih kepada Jurusan Fisika FMIPA UNTAD yang sudah memfasilitasi dalam penyelesaian tugas akhir ini. Trimakasih juga buat pembahas yang sudah memberikan saran-saran dalam penyempurnaan tulisan ini. Trimakasih buat teman-teman, kaka-kaka senior, dan adik junior di jurusan Fisika FMIPA UNTAD yang sudah membantu dalam penelitian ini.

\section{DAFTAR PUSTAKA}

[Bakosurtanal] Badan Koordinasi Survey dan Pemetaan Nasional (1991). Peta Rupa Bumi Indonesia Edisi Ke-1. Jalan Raya Jakarta-Bogor KM 46
Hidayat, R., dan Sampurno, J. (2015). Identifikasi lokasi bedrock menggunakan metode geolistrik konfigurasi wenner sebagai bahan acuan perancangan pondasi pembangunan gedung di daerah Sampit Kalimantan Tengah. Prisma fisika. 3. 41-46.

Santoso, J. (2002). Pengantar teknik geofisika.

Bandung: Penerbit ITB.

Telford, W., M., Geldart, L., P., and Sheriff, R.. (1990). Applied geophysics. Second edition. Cambridge University 